\title{
LeRon James Harrison*
}

\section{Staging Poetic Balance: A New Introduction to and Translation of the Noh Play Hakurakuten}

\author{
https://doi.org/10.1515/asia-2019-0014
}

\begin{abstract}
The introduction discusses the noh play Hakurakuten in relation to the earlier introduction to and translation of the play by Arthur Waley, the reading of the play by Leo Shingchi Yip, and the concepts of allusion and allusive space advanced by Joseph Pucci. Using Pucci's concepts, I discuss the allusions to literary texts, cultural practices, and historical events and persons in Hakurakuten in a new manner as well as assess the aspects of the play both Waley and Yip overlook and how Waley and Yip's readings fit into an allusive space reading of the play. The translation is based on the version of the play appearing in Itō Masayoshi's annotated volume and incorporates as much as possible the information Itō gives. It contains a translation of the kyōgen interlude, which is important to appreciating the central theme of the play and was left out of the Waley translation. It also contains more footnotes than the earlier Waley translation, notes that point out matters such as puns in language and source material for lines.
\end{abstract}

Keywords: noh, poetry, Bai Juyi, allusion, space

Hakurakuten as a noh play has largely gone unnoticed in scholarly studies of noh theater; this introduction and translation is an attempt to correct that trend. The play is one of the two hundred fifty noh plays in performance today; it is classified as a first category play (waki nō) according to the classification system developed in the Edo period. The authorship of the play is still in dispute, but the current working theory posits Zeami Motokiyo (c.1363-c.1443) as the initial author and his grandson Kanze Nobumitsu (?1435-1516) as a later editor. In the play, an envoy of the Chinese court named Hakurakuten travels to Japan to assess the wisdom of the people. He arrives at Tsukushi (the old name for Fukuoka) and encounters an old fisherman; the fisherman knows Hakurakuten's identity, is able to comprehend a couplet of Chinese poetry Hakurakuten recites and uses the couplet to

*Corresponding author: LeRon James Harrison, Global Languages, Murray State University, College of Humanities and Fine Arts, Faculty Hall 311-A, Murray, KY 42071, USA.

E-mail: Iharrison9@murraystate.edu 
create a verse of waka poetry. The fisherman, at the end of the first act, reveals himself to be the Sumiyoshi deity, the patron deity of waka poetry. In the interlude, a lesser deity from a branch shrine recaps the events of the first act and presents waka poetry as consolation to Hakurakuten. The second act opens with the Sumiyoshi deity in his true form coming out to dance for Hakurakuten; he summons other deities to play music for him and as he dances, he summons a wind that blows Hakurakuten back to China, bringing the play to an end.

In his introduction to the play Hakurakuten, Arthur Waley asserts that the play "deals with [the] literary peril" of Japanese poetry. His reading of the play sees Bai Juyi as a historical figure encased in a play that is a commentary on "a time when Japanese art and literature were again becoming subject to Chinese influence." In Waley's introduction to the play, there is no consideration of the structure of noh plays and how these structures might shape what appears in the play. Furthermore, in recent years Leo Yip has been examining plays such as Hakurakuten that have Chinese themes and motifs in them. Yip's study focuses on the deployment of Chinese themes and motifs in the play, "the dynamics between [Japan and China that] might have contributed to the staging of China in noh," and presents "an investigation of noh as a tool of social commentary and a manifestation of cultural adaption concerning China...."2 These matters suggest that it is time for a new translation and examination of the play.

Waley never takes the time to explain how he connects the play's content to the theme of literary peril of Japanese poetry; however, it is worth examining Waley's claim on the basis of allusion. In his book The Full-Knowing Reader, Joseph Pucci presents a theory of allusion that can speak to the play. To Pucci, allusion "functions only when it is constituted by a powerful reader outside of the specific orbits of signification and reference established by its language." In other words, Pucci asserts that although an author/writer creates an allusion through borrowed language, the reader is the person who brings it into being. Allusion comes to being in what Pucci calls "allusive space," the "mental place where the allusion is made to mean [something]." ${ }^{3}$ In case of noh, I would posit that Pucci's version of allusion is at work because the noh actor is not concerned with creating allusion but rather carrying out the practice of noh. By practice, I am referring to Todd May's definition of the term as "a regularity (or regularities) of behavior, usually goal-directed, that is socially normatively governed." "To the noh actor (or practitioner), lines in the

1 Waley 1979: 207.

2 Yip 2016: 1,2.

3 Pucci 1998: 39, 43.

4 May 2001: 8. Another way to understand May's definition is that a practice is behaviors that one engages in regularly (regularities of behavior) that usually have an aim in mind (goal-directedness), 
play are not understood in terms of allusion but rather in the ways in which they are recited (i. e. the regularities of behavior for and the normative governance of noh), the lines' relation to the character being portrayed (i. e. the social governance of noh), and the above matters' connection to the overall performance of the play (i. e. the goal-directedness of noh). Allusion in noh can only be completed by the reader/ spectator of the play, the person who is able to make meaning of the play in its entirety along with the allusions in the lines. In light of the fact that allusion in noh is working between a fifteenth century author and in the current case a twenty-first century reader, it might be better to amend Pucci's conception of allusive space to be a space that is produced by both author and reader and capable of allowing both their versions of allusive space to coexist. Similarly, the allusive space of the play allows non-contemporaneous persons and events to exist within that space. It is this version of allusion and allusive space that I wish to apply to the play.

Waley is right to see the title of the play as a marker of the allusive space. Hakurakuten is the Sino-Japanese rendering of Bai Letian, a nom de plum of the Tang Dynasty poet Bai Juyi (772-846). However, the allusion to the Tang poet is a complex one, due to the nature of this particular name. Hakurakuten has a specificity referring to the play as a whole and the character within it much in the same way that Othello, MacBeth and Hamlet do. At the same time Hakurakuten has a deictic aspect that points not only to the character within the play and the play in its entirety but also to Bai Juyi and thereby establishes a relation with the Tang poet. The relation spans two linguistic systems (Chinese and Japanese) and involves the name Bai Letian, the pen-name Bai Juyi composed under. The specificity of the name Hakurakuten with the play is obvious and easily accessible; however, it takes a full-knowing reader to make the deictic connections and use the name in both senses.

Hakurakuten is classified as mugen nō, a play "about dreams and phantasms, featuring in the shite role a being ... such as [a] god, ghost, demon or spirit...." More specifically, Hakurakuten is a waki nō or deity play. A common feature of mugen nō involves analepsis, a sense that one character is shifting between a time in the past and the "present" moment when the waki and shite, the two central characters of any noh play, meet. This temporal instability is usually fixed onto the shite, who due to attachments is unable to achieve enlightenment and is trapped in a cycle of karmic repetition. Waki nō, as Benito Ortolani explains, "usually... narrates the story of the origin of a shrine,

have roles that can be mastered by individuals (social governance), and have right and wrong ways of engagement (normative governance). See Harrison 2017 for an example of how May's conception of practice can be applied. 
or ... praises a kami." "In waki nō, the shite comes to reveal a divine secret. As the deities of waki nō are not bogged down in attachment, they are unlikely (if not impossible) candidates for this instability. Therefore, if any character in waki nō is to possess this analepsis, it would be the waki. By obscuring the identity of Bai Juyi, the play creates a stage version of the historical figure that this instability can be affixed to.

The analpsis that Waley appears to recognize is the disjunction of the poetry of Bai Juyi being put into an allusive space that also incorporates the Mongol Invasions of Japan. As the play opens, Hakurakuten announces that he came to "measure the wisdom of Japan." These lines being delivered by an emissary from China allude to the historical events where the emissaries of Kublai Khan delivered a letter which indirectly stipulated that Japan become a vassal state. However, there is no underlying military or political threat in Hakurakuten's statement; the threat of invasion is something the reader brings into the allusive space. The play concludes with Hakurakuten being blown back to the continent by a divine wind; this divine wind is the other bookend of the Mongol Invasion allusion. However, the wind in the play is generated by the dancing of the Sumiyoshi deity, rather than a natural phenomenon with a divine origin attributed to it afterwards. The combination of the poetry and penname of Bai Juyi and the Mongol Invasions are major bases of the allusive space of the play.

The central issue of the play is not about the "literary peril" of Japanese poetry, but rather the literary nature and effectiveness of Japanese poetry. Hakurakuten arrives to ascertain how wise and clever the Japanese people are; the Sumiyoshi deity responds to the potential incursion by appearing in the guise of a fisherman. Hakurakuten tries to display superiority by composing a Chinese poem, thinking the disguised deity will not understand. But, to Hakurakuten's surprise, the old man interprets the poem and then rephrases it into Japanese. Then, the Sumiyoshi deity reveals the connection between Japanese and Chinese poetry, drawing on the medieval commentary Kokin wakashū jo kikigaki (Lecture Notes on the Kana Preface of the Kokinshū). ${ }^{6} \mathrm{He}$ then cites lines from the Kana Preface of the Kokinshū and follows up by revealing a story behind one moment of interaction between Chinese and Japanese poetry in Japanese history, once again returning to the Kokin wakashū jo kikigaki. In the kyōgen interlude, a lesser deity who serves the Sumiyoshi deity reveals other poems that exemplify the principles of the kikigaki. After all of this is conveyed, the Sumiyoshi deity stirs up a divine wind that

5 Ortolani 1990: 132.

6 Katarigi 1973. 
blows Hakurakuten back to China. So, through the characters who appear on stage, the play relates the nature of Japanese poetry.

When the disguised Sumiyoshi deity and his companion make their entrance in the first act, they enter saying the following lines: "Place of the Unknown Fire/The seas of Tsukushi/In the dim lit dawn/a view with only a moon." In the original Japanese, these four lines alternate syllables in a pattern of 5-7-5-7, the same pattern as the first four lines of a waka poem. So, the description of Tsukushi is imbued with poetic resonance. But when the pair of fishermen express their opinion on the scenery they use Chinese poetry. "Han Rei, withdrawing from Etsu,/rowed in his small boat./And the mist of the Five Lakes/hung above his wake./So much alike, we realize/What a pleasant sea." These lines are drawn from two couplets of Chinese poetry found in the Wakan Rōeishū (Songs Sung in Japanese and Chinese). Moreover, these lines refer to the story of Fan Li (Han Rei in Japanese) and his departure from the kingdom of Yue (Etsu). ${ }^{7}$ It is only when the two fishermen realize that there is similarity between the present scenery and that of Fan Li that the two are pleased. So, the poetic resonance of this locale is not exclusive to Japanese poetry alone.

The Sumiyoshi deity gives the rationale behind this symbiosis between the two forms of poetry later in the first act. "The sutras of India are the origins of the poetry of China. The poetry of China is the basis of the uta of our Imperial court." These lines are from the Kokin wakashū jo kikigaki. ${ }^{8}$ In the original context, as Susan Blakeley Klein explains, these lines explain "why 'Yamato' [of yamatouta] should be written with the graphs 大和, which literally mean 'greatly gentled' or 'greatly harmonizing.",9 But at the same time they establish a "transitive" relationship among Buddhist sutras, Chinese poetry, and Japanese poetry. ${ }^{10}$ Because Chinese poetry draws from Buddhist sutras, Chinese poetry has the same divine power as the sutras. Likewise, Japanese poetry draws from Chinese poetry and possesses the same divine power. As a result, Chinese and Japanese poetry are equal as both have a power drawn from the sutras. Furthermore, a conflict between the two forms of poetry would result in a draw as both have the same divine power. So why is Hakurakuten defeated by the Sumiyoshi deity? The answer is that Hakurakuten is overpowered by the deity. The deity has both Chinese and Japanese poetry at his disposal; Hakurakuten has only his native

7 Fan Li was a minister to the King of Yue (Etsu) who lived in the fifth century B.C.E. Having served the king, Fan Li withdrew from court and rowed away from Yue.

8 Katarigi 1973.

9 Klein 2002: 226.

10 By "transitive" I am referring to the transitive property of equality in algebra: If $\mathrm{a}=\mathrm{b}$ and $\mathrm{b}=\mathrm{c}$, then $\mathrm{a}=\mathrm{c}$. 
verse. So, the deity has twice the divine power of poetry than Hakurakuten; in light of this, the Sumiyoshi deity shows Hakurakuten that he cannot win the poetic contest. The Sumiyoshi deity, in a conciliatory act, sends a lesser deity to compose a waka poem, giving Hakurakuten a taste of what he is missing. At the end of the kyōgen interlude, the Sumiyoshi deity affirms the harmonious interaction between Chinese and Japanese poetry, just before dismissing Hakurakuten back to China.

This symbiotic reading of Hakurakuten takes a different approach than Leo Yip's reading. Yip sees the play as depicting "Chinese culture as a threat to Japan and celebrat[ing] the superiority of Japanese culture over the Chinese." He reads Hakurakuten as a political statement out about fifteenth century diplomacy between China and Japan; his reading, however, comes about by overlooking the transitive argument the Sumiyoshi deity makes. Yip's reading also focuses on the divine wind-Mongol Invasion allusion, asserting the divine wind as "the product of the joint force of Shintō and Buddhist deities, promoting the notion that Japan is protected by the deities from both religions..."11 This reading of the divine wind in the second act follows a similar pattern as Yip's overlooking the transitive argument in the first act. The divine wind scene, in fact, maintains the symbiotic relationship between Japanese and Chinese culture.

Immediately after the lines announcing the appearance of various deities are the following lines: "Floating atop the sea/when they dance to the Sea Blue Music/ The eight dragon kings play/ the music of the eight instruments." "The Sea Blue Music" (Kaiseiraku) is a piece of music within the repertoire of gagaku, Japanese Imperial court music; however, this piece is identified as kangen, instrumental music, that is, music that is without a dance. So, when the Sumiyoshi deity says "he will dance to the Sea Blue Music" at the close of the first act, he is saying he will make a dance of his own to this instrumental piece. "The Sea Blue Music," like so much of the gagaku repertoire, has its origin in continental court music. The "eight instruments" the Sumiyoshi deity speaks of are not the eight instruments that gagaku uses, but rather the eight instruments used to perform yayue, the Confucian ritual music. ${ }^{12}$ So, what the Sumiyoshi deity is performing is not Japanese court music, but Chinese ritual music.

11 Yip 2007: 511, 512.

12 The eight instruments used in kangen are: the ryūteki (a 7 holed transverse flute), the hichiriki (a double reed instrument), the shō (a 17 pipe mouth organ), the gakubiwa (a 4 string lute), the gakusō (a 13 string zither), the shōko (a gong suspended in a wooden stand), the gakudaiko (a drum suspended in a wooden stand), and the kakko (a double headed drum). The eight instruments used in yayue are: the bell, the chime (a L-shaped chime made out of 
This fits with the statements the local deity who appears in the kyōgen interlude makes: “In accordance with the Sumiyoshi deity's oracular revelation, to lighten Hakurakuten's thoughts of having traveled so far we lesser gods have come forth; to console Hakurakuten, we have appeared first." The Sumiyoshi deity is dancing not merely to send Hakurakuten back to China but also to console him; as part of his consolation he has the deities perform "The Sea Blue Music" using continental instruments in a manner familiar to Hakurakuten. All of this follows the central argument the Sumiyoshi deity made in the first act: Chinese poetry and Japanese poetry share the same origin and the same source of power. Yip's reading of Hakurakuten in the fifteenth century can still be seen as valid in light of the argument of allusive space; that is, people in the fifteenth century read the play in light of dominant attitudes towards China and asserted the divine wind-Mongol Invasion allusion in stronger terms. However, this reading runs the risk of ignoring the central argument that runs through the play: that Japanese and Chinese poetry are similar in nature and one cannot be placed above or below the other.

Over the course of Hakurakuten, the dynamic between Chinese and Japanese poetry is not so hostile as Yip posits. An example of the interplay between poetic styles is the Chinese poem Hakurakuten composes and Sumiyoshi comments upon.

waki: Green moss - donned like a robe atop rocky shoulders.

White clouds resemble a sash

encircling the midrange of the mountains.

Do you understand it?

shite: The poem refers to the green moss hanging off rock shoulders and resembling a robe. The white clouds are like a sash encircling the midsection of the mountains. How amusing, how amusing. In Japanese uta, the same thing would go this way.
kokegoromo
kitaru iwao wa
samonakute
kinukinu yama no
obi wo suru kana
The rock draped in a green moss robe has no sash to close it while the robeless mountain fashions a sash.

stone), the zither, the flute, the mouth organ (shō), the earth pipe (an ocarina-like flute made out of clay with either 2, 3, or 5 holes), the drum and the rhythm box (a wooden box with a hole in one side; a rod is inserted into the hole and moved from side to side). 
The Sumiyoshi deity could not create the second poem without Hakurakuten creating the first. This connection between the two forms of poetry appears again in the origin story of the poem on the warbler.

In springtime each year

in the eaves of his dwelling a warbler would come and when he listened to it

it sang:

sho yō mai chō rai

fu sō gen hon sei

when he copied the sounds down

and gazed upon them

Indeed, there were 31 syllables

and one uta before him.

shite: hatsu haru no

Though I come

ashita goto ni wa

kitaredomo

every morning

at the beginning of spring

chorus: awade zo kaeru

moto no sumika ni

I return without meeting you

to my old nest.

In both examples, there is an interplay between Chinese and Japanese poetry. The Chinese poetry is the starting point that initiates the composition of Japanese poetry. Furthermore, in both cases there is a translation process occurring. The content expressed in the Chinese poem is rephrased into Japanese. This process of transference that is occurring in the play parallels a trend that was occurring during the fifteenth century.

David Pollack, in his book, notices the following trend occurring in the Muromachi period.

\footnotetext{
Poetry written in Chinese, too, was in this period coming to be regarded much like any other karamono, or "Chinese object"-such as the tea bowl whose original homely function was to all but disappear in the increasingly stylized ritual and connoisseurship of chanoyu....In other words, cultural and artistic forms once thoroughly alien to Japanese were in this period in the process of being emptied of their Chinese content and replaced with entire Japanese signification....In much the same fashion that other Chinese cultural artifacts were being subjected to new interpretations within a Japanese context, poems written in Chinese...were becoming objects to be esteemed... for their ceremonial and ornamental qualities. ${ }^{13}$
}

Pollack presents one option for Chinese objects and texts in the Muromachi period: removing their Chinese context and developing a Japanese context and

13 Pollack 1986: 151-152. 
meaning. Another option is exemplified by the idea of wakan (Japanese and Chinese), that is, the interplay between Japanese and Chinese in which both are combined to make a larger whole. This concept could be seen in poetic works such as the Wakan Rōeishū (The Collection of Songs Sung in Japanese and Chinese) and prose works such as Heike Monogatari (The Tale of Heike) which "use both Chinese characters and a [Japanese] syllabary in [their] transcription."14 In the Muromachi period, the concept appears in the linked verse of Chinese and Japanese (wakan renku) that poets like Nijō Yoshimoto participated in. And within the space of the play Hakurakuten Chinese and Japanese play off each other rather than Chinese poetry being recontextualized.

As a play, Hakurakuten has much that lends itself to scholarly consideration. The focus of this introduction has been on the allusion and allusive space of this play, which speaks to two distinct historical moments. However, this is only a portion of the allusive space. The depictions of China and Chinese poetry is also a part of the allusive space of the play; these depictions are the subject matter Leo Yip has begun to examine across several plays. The depiction of court music is another component of the allusive space in Hakurakuten; this aspect is something I am currently exploring across other noh plays. Allusion and allusive space reveals that this noh play has much material both literary and cultural to be considered within its lines; this introduction and translation hopefully will be a starting point for scholars to explore Hakurakuten and its connection to other literary and cultural works.

\section{Hakurakuten}

Classification:
Cast of Characters
waki
maeshite
shitetsure
ai
nochijite

nanori waki:
First-category play or waki noh

Hakurakuten, a courtier of the Tang Court
An old fisherman
An companion fisherman
A lesser deity who serves the Sumiyoshi deity
The Sumiyoshi deity

Act One

Before you is a courtier to the Prince of Tang China. Harurakuten be my name.

Now, to the east of here there is a county;

Nippon is the name it bears. ${ }^{15}$

14 Konishi 1986: 145.

15 Over the course of the play, Hakurakuten refers to Japan as Nippon while the shite uses Nihon. To maintain this distinction, I leave Nippon untranslated while translating Nihon. 
shidai

ageuta

kikiserifu

issei shite:
shitetsure:

sashi

shite:

shite:

\section{shitetsure:}

Having made preparations and been entrusted with a mission to travel to that land and measure the wisdom of its people, I now head out along the seaways. The boat rows out towards the rising sun The boat rows out toward the rising sun Towards that country I will visit. The Eastern Sea a boat traveling far along its wave-filled roads a boat traveling far along its wave-filled roads in its wake lies the light of a setting sun a sky with clouds streaming. From that place where the moon also rises mountains begin to come into view. And before I know it I have reached the shores of Nippon I have reached the shores of Nippon. So swiftly I have crossed the seaways the shores of Nippon are here before me. "Let us drop anchor for a while and gaze upon the nature of Nippon" now enters my mind.

Place of the Unknown Fire

The seas of Tsukushi ${ }^{16}$ In the dim lit dawn a view with only a moon. The ocean waters toss and toss The turquoise waves soak the sky. Han Rei, withdrawing from Etsu, rowed in his small boat. And the mist of the Five lakes hung above he waves. ${ }^{17}$ So much alike, we realize.

16 "Unknown Fire" is a translation for shiranui no, a makurakotoba (pillow word) for Tsukushi, the old name for Kyūshū. The word can also be written with the characters for "white seams". In the Itō version of the play, shiranui no is written kana, so both readings are possible.

17 "Han Rei" is Fan Li, a minister to the King of Yue (Etsu) who lived in the fifth century B.C.E. Having served the king, Fan Li withdrew from court and rowed away from Yue. These lines are drawn from poems \#406 and \#505 in the Wakan Rōeishū (Songs Sung in Chinese and Japanese). 


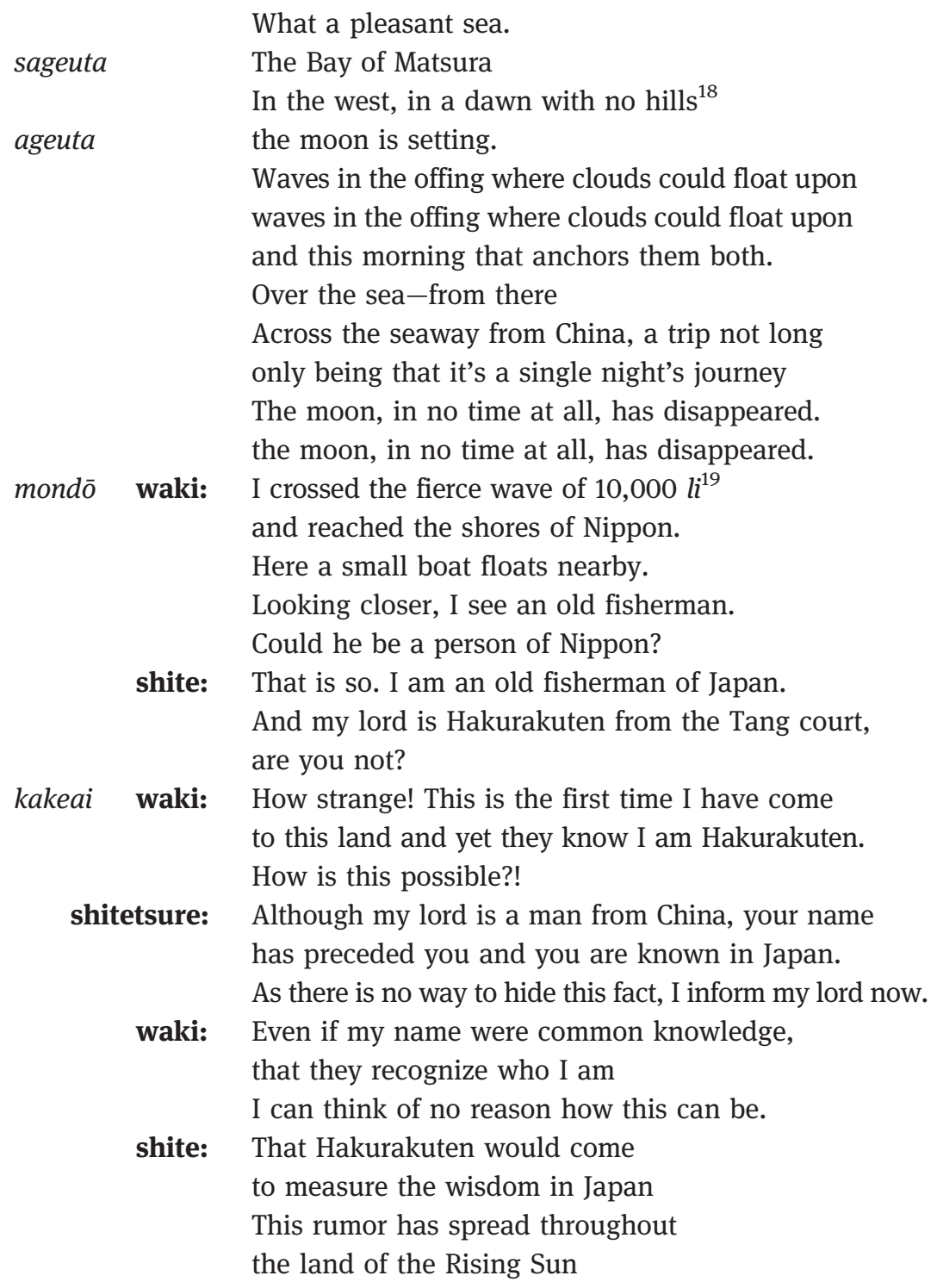

18 This line is inverting a conventional poetic image. Normally, the moon sinks behind a mountain ridge, here it does not.

19 A $l i$ is a measure of distance used both in China and Japan that is about 0.3 mile. 


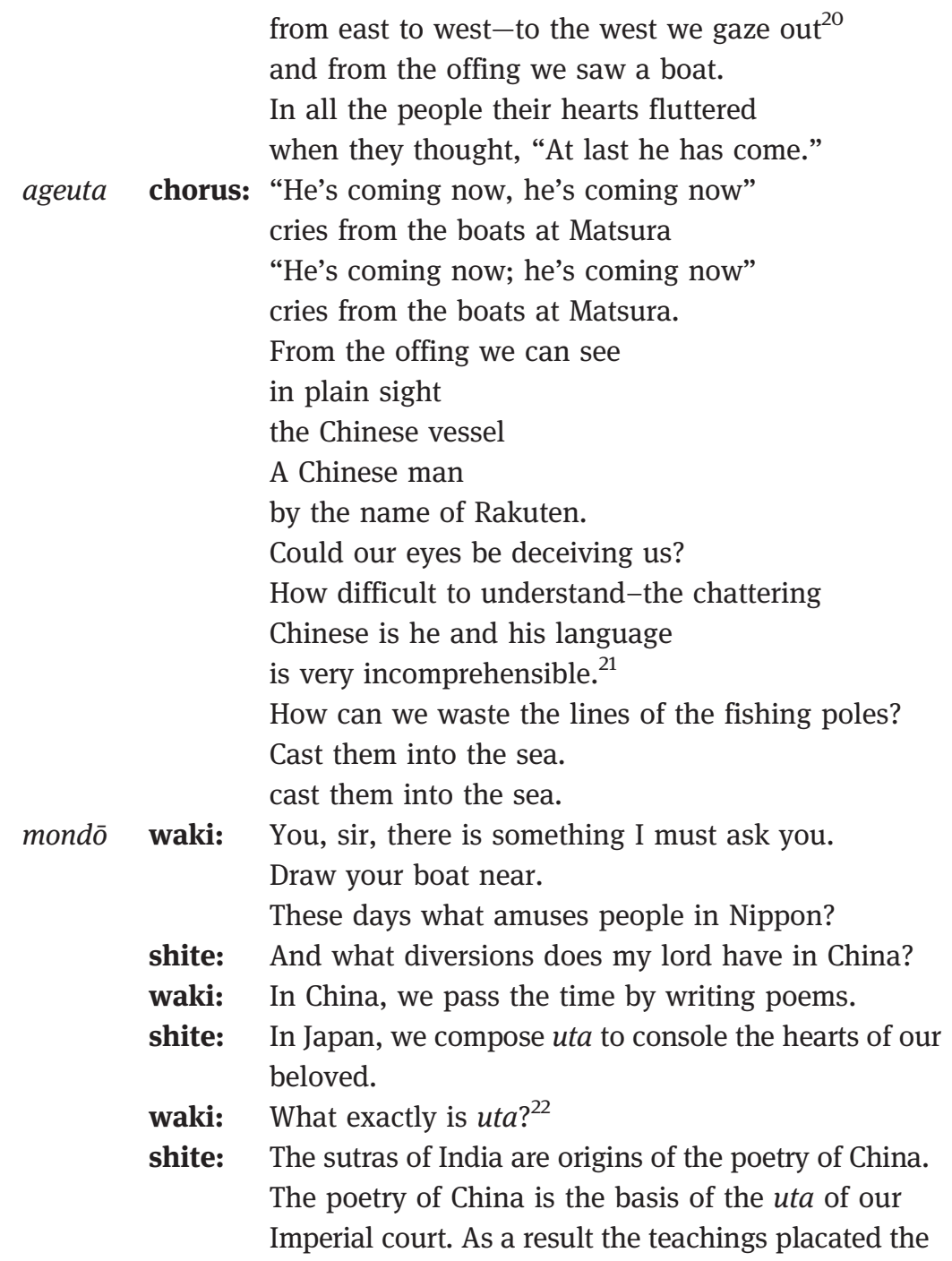

20 This line involves a play on west as the direction the rumors spread and the direction the fishermen look to spy Hakurakuten.

21 This line involves a play on the word iisayaku, to chatter, a makurakotoba for the kara (China) of karabito (a Chinese man).

22 Uta, also known as yamatouta or waka, is the poetry of Japan that consists of 31 syllables dispersed over five lines in the pattern of 5-7-5-7-7. All three terms are used by the shite over the course of the play. 
three kingdoms. It is written that they greatly harmonize, so we call them Yamatouta. ${ }^{23}$ My lord surely know this, but I presume that he is trying to see what an old man knows.

waki: No, I had no intent for that. Come, I will write a poem on the scenery before me. Listen to it.

Green moss - donned like a robe

atop rocky shoulders.

White clouds resemble a sash

encircling the waistline of the mountains.

Do you understand it?

shite: The poem refers to the green moss hanging off rocky shoulders and resembling a robe. The white clouds are like a sash encircling the midsection of the. mountains How amusing, how amusing. In Japanese uta, the same thing would go this way.

kokegoromo

kitaru iwao wa

samonakute

kinukinu yama no

obi wo suru kana
The rock draped in a green moss robe has no sash to close it while the robeless mountain fashions a sash.

kakeai waki: How strange! Though he is a poor fisherman, he composes a poem with such sentiment. What kind of person is he?

shite: I am an ordinary man, one without a name, and yet composing uta is not limited to man alone. For among all creatures that live and breathe, none are without song. 24

waki: Among the creatures that live and breathe - even fowl and beasts

shite: are examples of singing waka.

waki: In the land of Yamato, ${ }^{25}$

23 These lines are drawn from the medieval commentary Kokin wakashū jo kikigaki (Lecture Notes on the Kana Preface to the Kokinshū), a work attributed to Fujiwara no Tameaki.

24 These last two lines are drawn from the Kana Preface to the Kokinshū.

25 Hakurakuten uses the term wakoku, the Kingdom of Wa. Wa is the name Chinese used to refer to Japan. The characters for wakoku are read yamato no kuni in Japanese, which I have translated as "Land of Yamato." 
shite: such songs are many.

ageuta chorus: The warbler singing among the blossoms

Even the frog that dwells in the pond

For China, I do not know, but in Japan

we compose uta.

Even an old man,

when it comes to yamatouta,

indeed, he can compose one.

kuse

As for an example of

a composition on the warbler,

In the reign of Emperor Kōken, they say,

In the province of Yamato

a priest resided in a temple in Takama. ${ }^{26}$

In springtime each year

in the eaves of his dwelling a warbler

would come and when he listened to it

it sang:

sho yō mai chō rai

fu sō gen hon $\operatorname{sei}^{27}$

when he copied the sounds down

and gazed upon them

Indeed, there were 31 syllables

and one $u$ ta before him.

shite: hatsu haru no

Though I come

ashita goto ni wa

every morning

kitaredomo

at the beginning of spring

chorus: awade zo kaeru

I return without meeting you

moto no sumika ni

to my old nest.

Having heard "to my old nest" in its song

the warbler was the first.

And other fowl and beasts

like men sing the uta.

The examples are as numerous as

26 The Kokin wakashū jo kikigaki says that this story is from the Nihon Shoki (The Chronicles of Japan). The story goes that the old priest's acolyte died and was reborn as a warbler that visited the temple; no such story is found in the Nihon Shoki. Yamato Province is modern day Nara Prefecture and Takama is near the border between Nara and Ōsaka Prefectures.

27 The warbler, it turns out, is singing a Chinese couplet of poetry that has the same meaning as the uta that follows. 


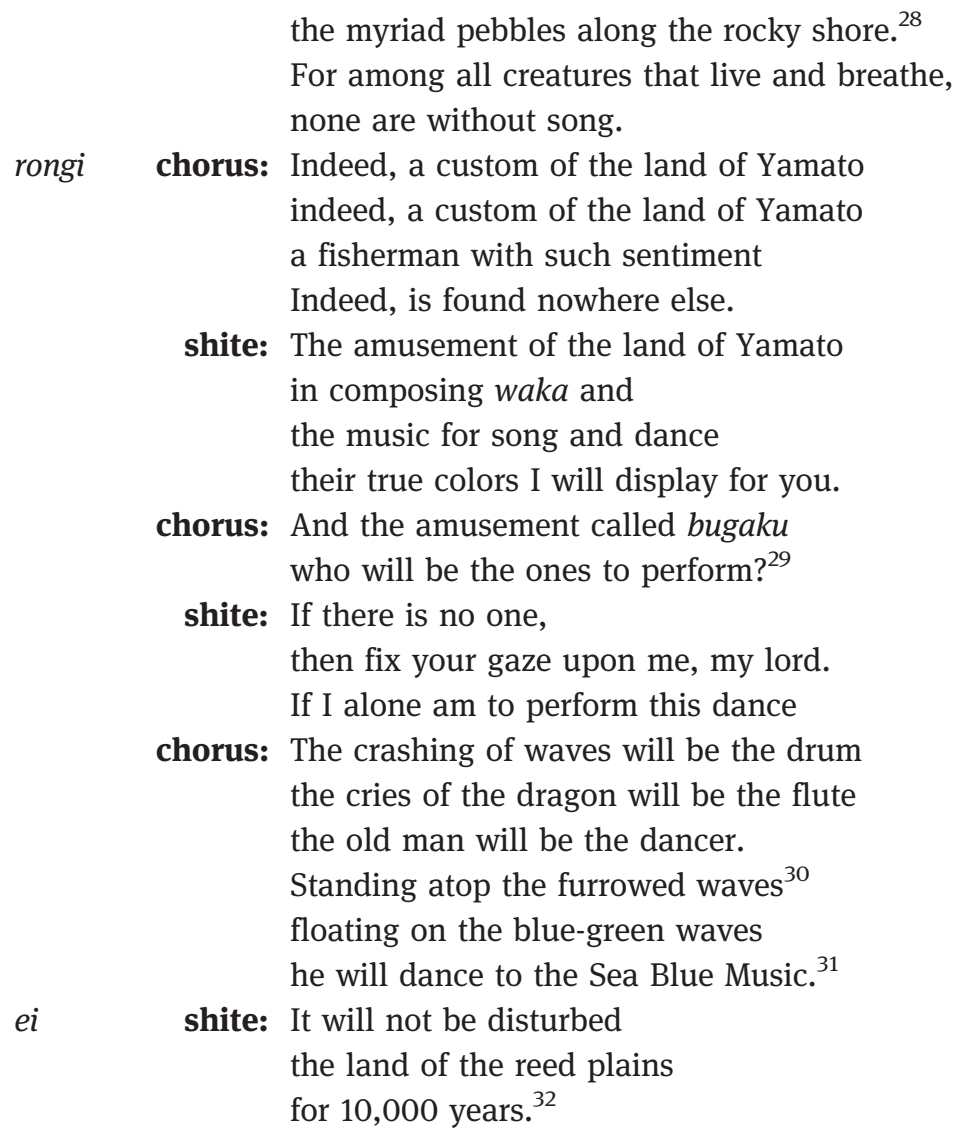

Kyōgen

ai: I am the deity of the local shrine, who serves the Sumiyoshi deity. The deity has heard that a man named Hakurakuten from Tang China has crossed the seas to our land saying he will measure the wisdom of Japan and that he has landed at this bay. The deity regarded his

28 These lines involve a play on the word ari in ōku ari (numerous) and arisoumi (rocky shore). 29 Bugaku is a performance of a dance set to an accompanying piece of court music. 30 "Furrowed waves" is oi no nami, a poetic term for old age. Here the word describes the waves the old man dances atop.

31 The "Sea Blue Music" is Kaiseiraku, a piece of kangen or ensemble music. As this is not a bugaku piece of music, there is no dance performed with it. So, the shite is performing an original dance to the music.

32 "The Land of the Reed Plains" (ashiwara no kuni) is a term used to refer to Japan. 
entry into Japan as a matter utmost importance so he took the guise of a lowly fisherman and rowed out in a small boat. When he drew near to the boat Hakurakuten was aboard, Hakurakuten turned toward the deity and asked, “Are you are a man of Japan?” To which the deity replied, "I am a fisherman of Japan." When Rakuten asked, "In Japan what do you do to amuse yourself?", the deity replied, "In Japan, we compose uta and console our hearts. Now in China what kind of things do have?” To which Rakuten replied, "At the Tang court, we write poetry to console our hearts.” Rakuten said, “A poor fisherman probably won't understand this but I will write a poem and let you hear it." After which he recited:

Green moss - donned like a robe atop rocky shoulders.

White clouds resemble a sash encircling the waistline of the mountains.

"Do you understand, old fisherman?” The deity heard this and said, "This sentiment is also in Japanese uta. I will use this poem's sentiment as the basis for an uta." He composed:

kokegoromo

kitaru iwao wa

samonakute

kinukinu yama no

obi wo suru kana
The rock draped in a green moss robe has no sash to close it while the robeless mountain fashions a sash.

Hakurakuten heard this and said, "A poor fisherman having this much poetic sentiment is truly strange." To which the deity replied, "It's a custom in the land of Yamato. For not only men but even fowl and beasts all things compose $u t a$. The Sanskrit sutras became the basis for Chinese poetry and our court took Chinese poetry to create uta. The teachings gathered in the three countries and it is written it greatly harmonizes, that is why we call it yamatouta. The warbler flew to the branches with plum blossoms and cried out a poem sho yō mai chō rai 
fu sō gen hon sei

The priest heard this and composed the following

hatsu haru no

Though I come

ashita goto ni wa every morning

kitaredomo

awade zo kaeru

at the beginning of spring

moto no sumika ni

I return without meeting you

to my old nest.

The uta composed on the frog is:

sumiyoshi no

As I never forget

ura no mirume mo

the seaweed I gaze upon

wasureneba

at the Bay of Sumiyoshi,

kari ni mo hito ni

even for a second I will not

towarenuru ka na

forget being visited by a man. ${ }^{33}$

And the uta written about the cow's drool is:

kusa mo ki mo

Upon hearing that

hotoke ni naru to

kiku toki wa

even plants and trees

kokoro aru mi wa

become bodhistavas

tanomoshiki ka na

this being with feelings

In this way the deity related the various examples. At

that moment, Rakuten was greatly shocked and thought,

"This is not what I expected Japan's wisdom to measure

up to. It is best if we return home.” That being the case, in accordance with the Sumiyoshi deity's oracular revelation, to lighten Hakurakuten's thoughts of having traveled so far, we lesser gods have come forth; to console Hakurakuten, we have appeared first. As we know he wishes that he could compose an uta, we offer this one:

sumiyoshi no

In a corner of

sumi ni suzume no

the Sumiyoshi Shrine

33 The Kokin wakashū jo kikigaki attributes this poem to the Nihon Shoki and gives the following story on its origins. A courtier by the name of Ki no Yoshitada went to Sumiyoshi and encountered a beautiful woman. He promised to return to her, to which she responded that if he was really in love with her that he should meet her at the shore. Yoshitada did so only to find a frog. The frog hopped around on the sand and wrote out the above poem. As with the warbler story, no such story appears in the Nihon Shoki.

34 The origins of this poem are not known. 


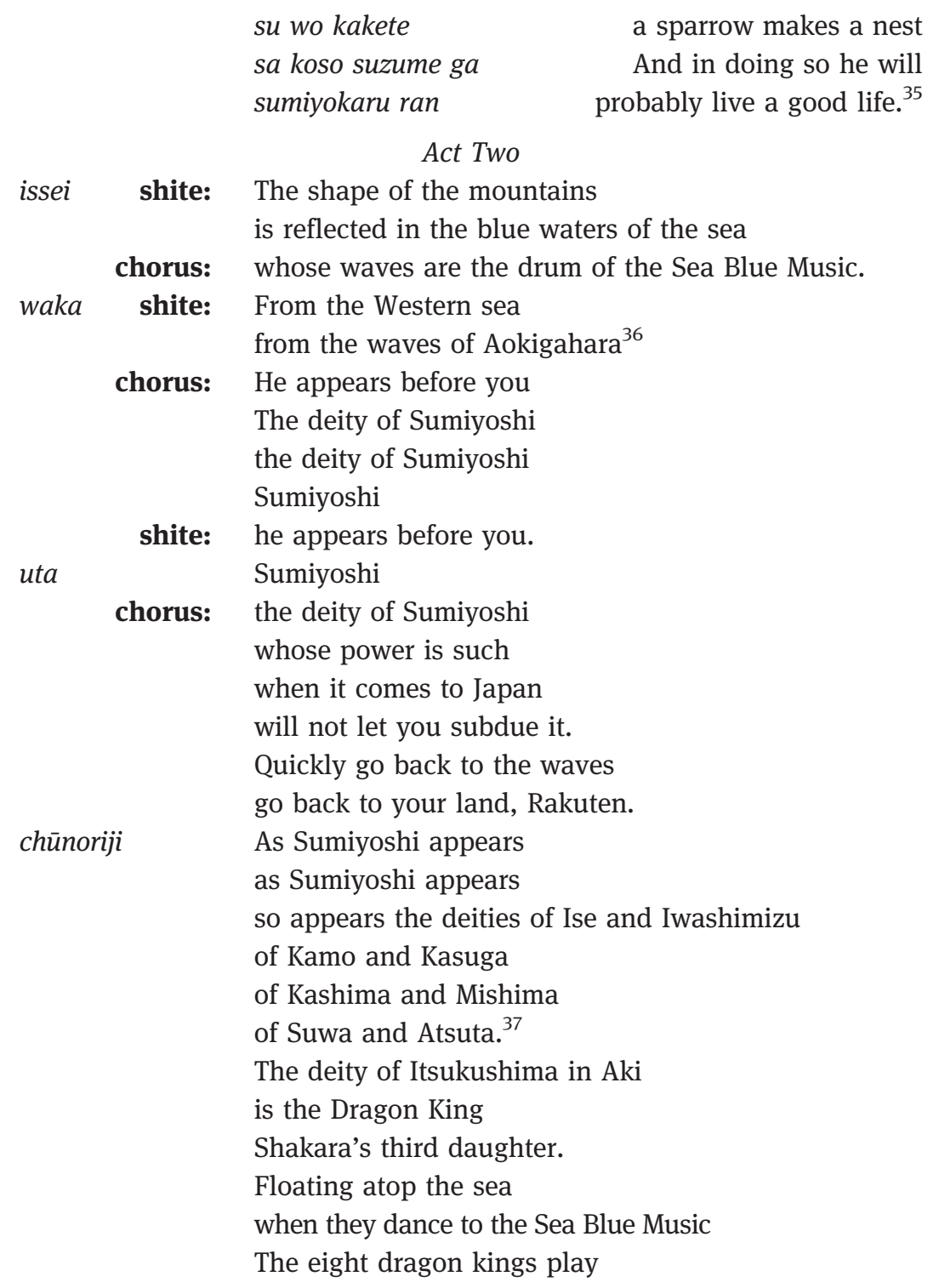

35 This poem involves alliteration of the "s" sound and a play on the place name sumiyoshi and its components sumi (to live) and yoshi (good).

36 Aokihara, also known as Awakihara, is the place where, according to the Kojiki and Nihon Shoki, Izanagi performed ablutions after he left the Land of the Dead (Yomi).

37 While the chorus says this, none of these deities appear on the stage. 


\begin{abstract}
the music of the eight instruments. ${ }^{38}$
As they soar in the empty sky, the heavenly robes they dance in their sleeves stir a wind, a divine wind that blow it back, that Chinese boat, from here to the land of the Han. Indeed there are none like them, our deities and sovereign. Indeed there are none like them the age of the gods and our sovereign. How auspicious our undisturbed land, how auspicious our undisturbed land.
\end{abstract}

\section{Bibliography}

Harrison, LeRon James (2017): “Gagaku as Place and Practice: A Philosophical Inquiry into the Place of lapanese Imperial Court Music in Contemporary lapanese Culture”. Asian Music: 4-27.

Itō, Masayoshi 伊藤正義 (annot.) (1988): Yōkyoku Shū. 謡曲集 (Vol. 79, Shinchō Nihon Koten Shūsei 新潮日本古典集成). Tokyo 東京: Shinchōsha 新潮社.

Katagiri, Yōichi 片桐洋一 (ed.) (1973): Chūsei Kokinshū chūshaskusho kaidai 中世古今集注釈書 解題 Vol. 2. Kyoto 京都: Akao Shōbundō 赤尾照文堂.

Klein, Susan Blakeley (2002): Allegories of Desire: Esoteric Literary Commentaries of Medieval Japan. Cambridge: Harvard University Press.

Konishi, Jin'ichi (1986): A History of Japanese Literature. (Vol. 2, The Early Middle Ages). Translated by Aileen Gatten. Princeton: Princeton University Press.

May, Todd (2001): Our Practices, Our Selves. Or, What It Means to Be Human. University Park, Pennsylvania: Pennsylvania State University Press.

Ortolani, Benito (1990): The Japanese Theatre: From Shamanistic Ritual to Contemporary Pluralism. Princeton: Princeton University Press.

Pollack, David (1986): The Fracture of Meaning: Japan's Synthesis of China from the Eighth through the Eighteenth Centuries. Princeton: Princeton University Press.

Pucci, Joseph (1998): The Full-Knowing Reader:Allusion and the Power of the Reader in the Western Literary Tradition. New Haven and London: Yale University Press.

38 The eight instruments are: the bell, the chime (a L-shaped chime made out of stone), the zither, the flute, the pipe organ (shō), the earth pipe (an ocarina-like flute made out of clay with either 2, 3, or 5 holes), the drum and the rhythm box (a wooden box with a hole in one side; a rod is inserted into the hole and moved from side to side). These eight instruments are used in yayue, the ritual music of the Chinese court. In gagaku, only the zither, the flute, the pipe organ, and the drum are actually used. 
Waley, Arthur (1979): The Noh Plays of Japan. Rutland: Charles E. Tuttle Company.

Yip, Leo Shingchi (2007): "Nō as Sociopolitical Commentary: Staging Chinese Literari in Medieval №̄ Theatre”. Asian Theatre Journal 24.2: 505-517.

Yip, Leo Shingchi (2016): China Reinterpreted: Staging the Other in Muromachi Noh Theater. Lanham, Maryland: Lexington Book. 